\title{
Characterization of the ompLI gene of pathogenic Leptospira species in China and cross-immunogenicity of the OmpLI protein
}

\author{
Haiyan Dong1,2, Ye Hu${ }^{3}$, Feng Xue ${ }^{1,2}$, Dexter Sun ${ }^{4}$, David M Ojcius ${ }^{5}$, \\ Yafei $\mathrm{Mao}^{1,2}$ and Jie Yan*1,2
}

\begin{abstract}
Address: ${ }^{1}$ Division of Basic Medical Microbiology, State Key Laboratory for Diagnosis and Treatment of Infectious Diseases, the First Affiliated Hospital of Medical College, Zhejiang University, Hangzhou Zhejiang, PR China, ${ }^{2}$ Department of Medical Microbiology and Parasitology, Medical College of Zhejiang University, Hangzhou Zhejiang, PR China, ${ }^{3}$ Medical School of Jinhua Professional Technique College, Jinhua Zhejiang, PR China, ${ }^{4}$ New York Presbyterian Hospital \& Hospital for Special Surgery, Weill Medical College, Cornell University, New York, NY, USA and ${ }^{5}$ School of Natural Sciences, University of California, Merced, CA, USA

Email: Haiyan Dong - yanzidong1973@hotmail.com; Ye Hu - huye8254@sina.com; Feng Xue - sherlock_hsueh@hotmail.com; DexterSun - dextersun@sinaunitedhealth.com; David M Ojcius - dojcius@ucmerced.edu; Yafei Mao - myf@zju.edu.cn; Jie Yan* - med_bp@zju.edu.cn

* Corresponding author
\end{abstract}

Published: 17 December 2008

BMC Microbiology 2008, 8:223
Received: I September 2008

Accepted: 17 December 2008

This article is available from: http://www.biomedcentral.com/I47|-2/80/8/223

(C) 2008 Dong et al; licensee BioMed Central Ltd.

This is an Open Access article distributed under the terms of the Creative Commons Attribution License (http://creativecommons.org/licenses/by/2.0), which permits unrestricted use, distribution, and reproduction in any medium, provided the original work is properly cited.

\begin{abstract}
Background: The usefulness of available vaccine and serological tests for leptospirosis is limited by the low cross-reactivity of antigens from numerous serovars of pathogenic Leptospira spp. Identification of genus-specific protein antigens (GP-Ag) of Leptospira would be important for development of universal vaccines and serodiagnostic methods. OmpLI, a transmembrane porin of pathogenic leptospires, was identified as a possible GP-Ag, but its sequence diversity and immune cross-reactivity among different serovars of pathogenic leptospires remains largely unknown.
\end{abstract}

Results: PCR analysis demonstrated that the ompLI gene existed in all 15 official Chinese standard strains as well as 163 clinical strains of pathogenic leptospires isolated in China. In the standard strains, the ompLI gene could be divided into three groups (ompLI/I, ompL//2 and ompLI/3) according to their sequence identities. Immune electron microscopy demonstrated that all products of the different gene types of ompLI are located on the surface of leptospires. The microscopic agglutination test revealed extensive yet distinct cross-immunoagglutination among the antisera against recombinant $\mathrm{OmpLI}(\mathrm{rOmpLI})$ and leptospiral strains belonging to different ompLI gene types. These cross-immunoreactions were further verified by ELISAs using the OmpLI proteins as the coated antigens in serum samples from 385 leptospirosis patients. All the antisera against rOmpLI proteins could inhibit $L$. interrogans strain Lai from adhering to J774A.I cells. Furthermore, immunization of guinea pigs with each of the rOmpLI proteins could cause crossimmunoprotection against lethal challenge with leptospires from different ompLI gene types.

Conclusion: Three types of the ompLI gene are present in pathogenic leptospires in China. OmpLI is an immunoprotective GP-Ag which should be considered in the design of new universal vaccines and serodiagnostic methods against leptospirosis. 


\section{Background}

Leptospirosis, caused by infection with pathogenic Leptospira species belonging to different serogroups and serovars, is one of the most prevalent zoonotic diseases in the world [1-3]. A wide variety of serogroups and serovars have been identified along with endemicity which varies from region to region [4-6]. The leptospiral vaccines used currently are mainly multivalent dead whole-cell mixtures made of several local dominant serovars in different countries and regions. These vaccines, however, do not confer cross-protective immunity to the serogroups that are not represented in the vaccine $[7,8]$, allowing the unrepresented serovars to continue causing outbreaks of leptospirosis. For instance, in a central province, Anhui, and an eastern province, Zhejiang, of China, L. interrogans serogroup Sejroe serovar Medanensis caused local outbreaks of leptospirosis [9-12]. In addition, vaccination with the whole-cell vaccines may lead to incomplete, short-term immunity as well as serious side effects [1315]. A universal vaccine against leptospirosis is not available yet, making the identification of genus-specific protein antigens (GP-Ag) that display extensive crossimmunity very valuable for developing new vaccines and serodiagnostic methods.

Outer membrane proteins (Omps) are important pathogenic components and highly conserved in different serogroups and serovars of pathogenic leptospires. OmpL1, a transmembrane Omp with 320 amino acid residues, first reported by Haake and his colleagues in 1993, is a porin expressed by all the tested pathogenic Leptospira species [16-19]. However, the diversity of ompL1 gene sequences from different pathogenic Leptospira spp. and the distribution of the ompL1 gene in clinical isolates had not been characterized until now. Moreover, the cross-immunogenicity and immunoprotective effects of OmpL1 were mostly unknown.

In this study, we sequenced and analyzed ompL1 genes cloned from standard pathogenic strains of leptospires prevalent in China. Several prokaryotic recombinant products of the gene (rOmpL1) were expressed and their rabbit antisera were prepared. rOmpL1-based ELISAs were established to examine specific antibodies in sera from leptospirosis patients. In parallel, the microscopic agglutination test (MAT) was performed to detect the crossimmunoagglutination of different antisera against rOmpL1 proteins, and immunoelectron microscopy (IEM) was employed to localize OmpL1 on the leptospires. Finally, immunoprotection of rOmpL1 was tested in guinea pigs. Taken together, our results suggest that OmpL1 could be used as a major component of a universal and efficient immunogen for vaccination and also for diagnosis of leptospirosis.

\section{Results \\ Amplification of ompLI genes in the standard and clinical strains}

All the 15 standard strains and 163 isolates of pathogenic Leptospira species (Table 1) carried the ompL1 gene, since amplicons with the expected size were produced by PCR from all the strains and isolates (data no shown).

\section{Molecular phylogeny and gene-typing of ompLI gene}

Based on the molecular phylogenetic relationship of their nucleotide sequences (GenBank Accession No:: AY622658-AY622672) and putative amino acid sequences (Figure 1, see Additional file 1 for details), ompL1 genes from the pathogenic leptospires could be classified into three groups: ompL1/1, ompL1/2 and ompL1/ 3 (Table 2). Sequence identity of the putative amino acid sequences between ompL1/1 and ompL1/2,ompL1/1 and ompL1/3, and ompL1/2 and ompL1/3 gene types was $92.50 \%-93.44 \%$, $85.31 \%-86.88 \%$, and $85.31 \%-$ $86.25 \%$, respectively. In addition, the ompL1 gene sequencing data of 39 clinical strains also supported the classification into three groups (Table 2). Both the nucleotide and putative amino acid sequence identities among the clinical strains with the same ompL1 gene type were above $98 \%$ (data not shown).

\section{Data of secondary structure analysis of OmpLI proteins}

All the three gene types of OmpL1 proteins had very similar predicted secondary structures and antigenic indexes (Figure 2, see Additional file 2 for details). The OmpL1 proteins had five main putative surface-membrane regions (70-80, 115-120, 145-150, 235-245, 305-310 amino acid residuals) and seven transmembrane regions (10-40, 120-130, 160-190, 215-225, 240-250, 270280, and 295-305 amino acid residues). The only salient different was the presence of less alpha-helix in the N-terminal and beta-sheet in the C-terminal region of the OmpL1/3 sequence, compared to the sequences of OmpL1/1 and OmpL1/2.

\section{Identification of expressed rOmpLI proteins and titers of rabbit antisera}

rOmpL1/1, rOmpL1/2 and rOmpL1/3 were well expressed after induction with IPTG and showed single bands in gel after purification by Ni-NTA-chromatography (Figure 3). Western blot analysis also indicated that serum samples from leptospirosis patients could recognize rOmpL1 proteins (Figure 4), implying that the proteins are immunogenic during natural infection. Immunodiffusion titers of all the rabbit antisera against rOmpL1 proteins were at least 1:4.

\section{Localization of OmpLI proteins on leptospires}

Using anti-rOmpL1/1, anti-rOmpL1/2 and anti-rOmpL1/ 3 sera as the primary antibodies, all the colloidal gold par- 
Table I: Background information on the leptospiral strains and serum specimens

\begin{tabular}{|c|c|c|c|}
\hline Strain/Sera & Serovar & Serogroup & Genospecies \\
\hline \multicolumn{4}{|l|}{ Standard strains $(n=15)$} \\
\hline Lai & Lai & Icterohaemorrhagiae & L. interrogans \\
\hline Lin & Canicola & Canicola & L. interrogans \\
\hline Tian & Pyrogenes & Pyrogenes & L. interrogans \\
\hline $\operatorname{Lin} 4$ & Autumnalis & Autumnalis & L. interrogans \\
\hline $65-9$ & Australis & Australis & L. interrogans \\
\hline Luo & Pomona & Pomona & L. interrogans \\
\hline $\operatorname{Lin} 6$ & Grippotyphosa & Grippotyphosa & L. interrogans \\
\hline P 7 & Hebdomadis & Hebdomadis & L. interrogans \\
\hline L 37 & Paidjan & Bataviae & L. interrogans \\
\hline L 183 & Wolffi & Sejroe & L. interrogans \\
\hline$M 10$ & Javanica & Javanica & L. borgpetersenii \\
\hline Pishu & Ballum & Ballum & L. borgpetersenii \\
\hline $55-52$ & Tarassovi & Tarassovi & L. borgpetersenii \\
\hline Nan 10 & Mini & Mini & L. borgpetersenii \\
\hline L 105 & Manhao 2 & Manhao & L. weilii \\
\hline \multicolumn{4}{|l|}{ Isolates $(n=163)$} \\
\hline 85 & Lai & Icterohaemorrhagiae & L. interrogans \\
\hline 5 & Canicola & Canicola & L. interrogans \\
\hline 4 & Autumnalis & Autumnalis & L. interrogans \\
\hline 18 & Pomona & Pomona & L. interrogans \\
\hline 11 & Grippotyphosa & Grippotyphosa & L. interrogans \\
\hline 15 & Hebdomadis & Hebdomadis & L. interrogans \\
\hline 20 & Medanesis & Sejroe & L. interrogans \\
\hline 5 & Australis & Australis & L. interrogans \\
\hline \multicolumn{4}{|l|}{ Patient sera $(n=385)$} \\
\hline 191 & Lai & Icterohaemorrhagia & L. interrogans \\
\hline 11 & Canicola & Canicola & L. interrogans \\
\hline 13 & Autumnalis & Autumnalis & L. interrogans \\
\hline 37 & Pomona & Pomona & L. noguchii \\
\hline 31 & Grippotyphosa & Grippotyphosa & L. interrogans \\
\hline 44 & Hebdomadis & Hebdomadis & L. interrogans \\
\hline 45 & Medanesis & Sejroe & L. interrogans \\
\hline 13 & Australis & Australis & L. interrogans \\
\hline Normal sera $(n=36)$ & I & I & I \\
\hline
\end{tabular}

ticles conjugated to secondary antibodies were bound on the surface of $L$. interrogans serovar Autumnalis strain Lin 4 (ompL1/1 gene type), serovar Lai strain Lai (ompL1/2 gene type), and $L$. borgpetersenii serovar Ballum strain Pishu (ompL1/3 gene type) (Figure 5).

\section{Titers of MAT}

The antisera against rOmpL1/1, rOmpL1/2 and rOmpL1/ 3 were able to cross-agglutinate with MAT titers of 1:100 to $1: 800$ for all the 15 standard strains and 163 clinical strains of pathogenic leptospires (Table 3 ).

\section{Detection of antibodies against rOmpLI proteins in leptospirosis patients}

In ELISA assays using rOmpL1/1, rOmpL1/2 and rOmpL1/3, the positive rates for IgG in specimens from 385 leptospirosis patients using 1:100 and 1:200 serum dilutions were $87.8 \%(338 / 385)$ and $78.2 \%(301 / 385)$, $95.1 \%(366 / 385)$ and $82.1 \%(316 / 385)$, and $77.7 \%$
(299/385) and 65.5\% (252/385), respectively (Table 4). When using 1:50 and 1:100 serum dilutions from the same specimens, the positive rates for IgM were $83.4 \%$ (321/385) and 72.7\% (280/385), 87.0\% (335/385) and $77.4 \%(298 / 385)$, and $74.3 \%(286 / 385)$ and $63.1 \%$ (243/385), respectively (Table 4$)$.

\section{Inhibition of adherence by antisera against rOmpLI proteins}

Anti-rOmpL1/1 (1:200 dilution), anti-rOmpL1/2 (1:300 dilution) or anti-rOmpL1/3 (1:50 dilution) sera could completely inhibit the adherence of $L$. interrogans serovar Lai strain Lai to macrophages (Figure 6), demonstrating cross-inhibition effects among the different anti-sera.

\section{Immunoprotection due to immunization with rOmpLI proteins}

Immunization of guinea pigs with $\mathrm{rOmpL} 1 / 1, \mathrm{rOmpL} 1 / 2$ and $\mathrm{rOmpL} 1 / 3$ conferred a significant level of resistance 
Table 2: ompLI gene types of standard strains and isolates of Leptospires

\begin{tabular}{|c|c|c|c|c|c|c|}
\hline \multirow[t]{2}{*}{ Species } & \multirow[t]{2}{*}{ Serogroup } & \multirow[t]{2}{*}{ Serovar } & \multirow[t]{2}{*}{ Strain $(n)$} & \multicolumn{3}{|c|}{ ompLI gene type } \\
\hline & & & & I & 2 & 3 \\
\hline \multirow[t]{2}{*}{ L. interrogans } & Icterohaemorrhagiae & Lai & Lai & & $\sqrt{ }$ & \\
\hline & & & Wild (5) & & $\sqrt{ }$ & \\
\hline \multirow[t]{2}{*}{ L. interrogans } & Canicola & Canicola & Lin & & $\sqrt{ }$ & \\
\hline & & & Wild (5) & & $\sqrt{ }$ & \\
\hline \multirow[t]{2}{*}{ L. interrogans } & Australis & Australis & $65-9$ & & $\sqrt{ }$ & \\
\hline & & & Wild (5) & & $\sqrt{ }$ & \\
\hline \multirow[t]{2}{*}{ L. interrogans } & Pomona & Pomona & Luo & & $\sqrt{ }$ & \\
\hline & & & Wild (5) & & $\sqrt{ }$ & \\
\hline \multirow[t]{2}{*}{ L. interrogans } & Hebdomadis & Hebdomadis & P 7 & & $\sqrt{ }$ & \\
\hline & & & Wild (5) & & $\sqrt{ }$ & \\
\hline \multirow[t]{2}{*}{ L. interrogans } & Autumnalis & Autumnalis & $\operatorname{Lin} 4$ & $\sqrt{ }$ & & \\
\hline & & & Wild (4) & $\sqrt{ }$ & & \\
\hline \multirow[t]{2}{*}{ L. interrogans } & Grippotyphosa & Grippotyphosa & $\operatorname{Lin} 6$ & $\sqrt{ }$ & & \\
\hline & & & Wild (5) & $\sqrt{ }$ & & \\
\hline \multirow[t]{2}{*}{ L. interrogans } & Sejroe & Wolffi & L 183 & $\sqrt{ }$ & & \\
\hline & & Medanesis & Wild (5) & $\sqrt{ }$ & & \\
\hline L. interrogans & Bataviae & Paidjan & L 37 & & $\sqrt{ }$ & \\
\hline L. interrogans & Pyrogenes & Pyrogenes & Tian & & & $\sqrt{ }$ \\
\hline L. borgpetersenii & Javanica & Javanica & M 10 & & & $\sqrt{ }$ \\
\hline L. borgpetersenii & Ballum & Ballum & Pishu & & & $\sqrt{ }$ \\
\hline L. borgpetersenii & Tarassovi & Tarassovi & $55-52$ & & & $\sqrt{ }$ \\
\hline L. borgpetersenii & Mini & Mini & Nan 10 & & & $\sqrt{ }$ \\
\hline L. weilii & Manhao & Manhao II & L 105 & & $\sqrt{ }$ & \\
\hline
\end{tabular}

against lethal challenge with pathogenic leptospires from the three different ompL1 groups (Table 5). However, the immunoprotective rates against the same ompL1 gene type leptospiral infection as the immunizing recombinant protein $(62.5 \%-87.5 \%)$ were higher than when strains and proteins from different ompL1 gene types were used $(25.0 \%-62.5 \%)$.

\section{Discussion}

Outer membrane proteins exposed on the surface of leptospires are known to react with the host cell and environment. Interestingly, lipopolysaccharide fractions confer protective immunity against challenge with homologous but not heterogonous leptospires, whereas protein extract induced significant protection against both types of challenge [20]. Thus far, a number of outer membrane proteins of leptospires, such as OmpL1, LipL32, LipL36, LipL41, LigA and LigB, have been cloned and characterized, and some of them have been shown to stimulate specific immunity in animal models [21-24]. Among all the leptospiral Omps, OmpL1 is a unique transmembrane protein that was confirmed to function as a porin, contribute to the survival of leptospires, and display synergetic immunoprotection with LipL41 [16-18]. However, major questions such as the distribution of ompL1 gene types in leptospiral strains, the exact localization of OmpL1, and cross-immunogenicity and immunoprotective effects of OmpL1 proteins remain unaddressed.
This study reveals that the ompL1 gene is present in the genomes of all the pathogenic leptospires tested. According to our alignment and phylogenetic analysis from the 15 standard strains of pathogenic Leptospira spp., three groups of ompL1 (ompL1/1, ompL1/2 and ompl/3) exist. However, the predicted secondary structure of the OmpL1 proteins revealed that there is little difference among the three groups. Thus, the differences in nucleotide sequences in the ompL1 gene types may not affect the immunogenicity and OmpL1 proteins, identifying OmpL1 as a genus-specific protein antigen.

Surface exposure is a key characteristic for an effective antigen. Although OmpL1 may be an outer membrane protein according to previous reports, the precise localization of OmpL1 still remained unclear. Leptospires possess both inner and outer membranes, but only the proteins expressed in the outer membrane are capable of interacting with the host immune system. To begin to characterize the localization, we used the prokaryotic recombinant expression technique to obtain a large amount of homogeneous OmpL1 proteins for preparation of immunoresponsive antisera from rabbits. Visualization by immunoelectron microscopy using anti-OmpL1 anti-sera confirmed that OmpL1 is located at the surface of the outer membrane of leptospires. MAT is a standard method for serodiagnosis of leptospirosis and serological classification of leptospires, for which live leptospiral cells are typ- 


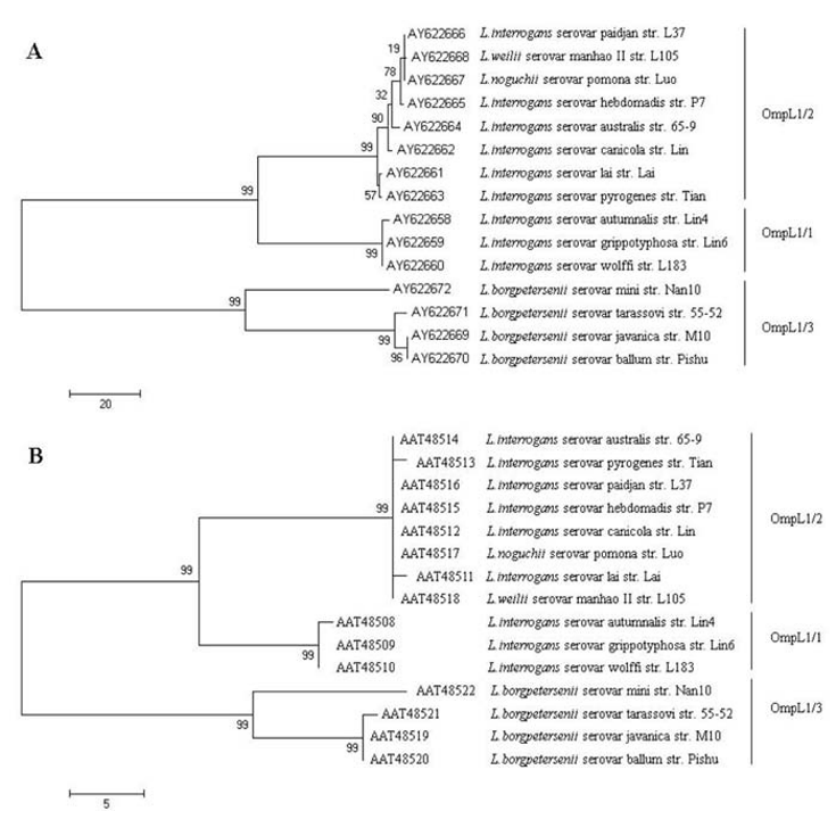

Figure I

Maximum parsimony trees for ompLI nucleotide sequences $(A)$ and its amino acid sequences $(B)$ of I 5 standard strains. This figure shows the upper quartile, for the full image please see Additional file I. The numbers at each fork node indicate the bootstrapping values (shown only when $>50 \%$ ). RefSeq accession number and abbreviation for the organism are shown at each relevant branch. The scale bar indicates the number of character substitutions.

ically used [23]. In this study, we used MAT to examine cross-immunoagglutination among the antisera from rOmpL1 proteins and a large number of strains belonging to different pathogenic leptospiral serogroups/serovars. The results indicated that there is extensive cross-immunoagglutination between the different $o m p L 1$ gene types of pathogenic leptospiral strains and the OmpL1 antisera, and not surprisingly, the highest agglutination was observed between antisera from the same ompL1 gene types as the leptospiral strains. Furthermore, ELISA results revealed that OmpL1s-specific antibodies are produced in all the sera from leptospirosis patients, and the trends in cross-immunoreactivities in the different ELISA tests are also similar to those of MAT.

At least 75 serovars of pathogenic leptospires belonging to 18 serogroups have been found to date in China, but only a few of them frequently cause leptospirosis. According to the annual reports on leptospirosis from Chinese CDCs, L. interrogans serogroup Icterohaemorrhagiae serovar Lai is the most dominant pathogenic leptospires, responsible for approximately $75 \%$ of the morbidity in the country. The other pathogenic leptospires causing leptospirosis are the Grippotyphosa, Autumnalis, Australis, Pomona and

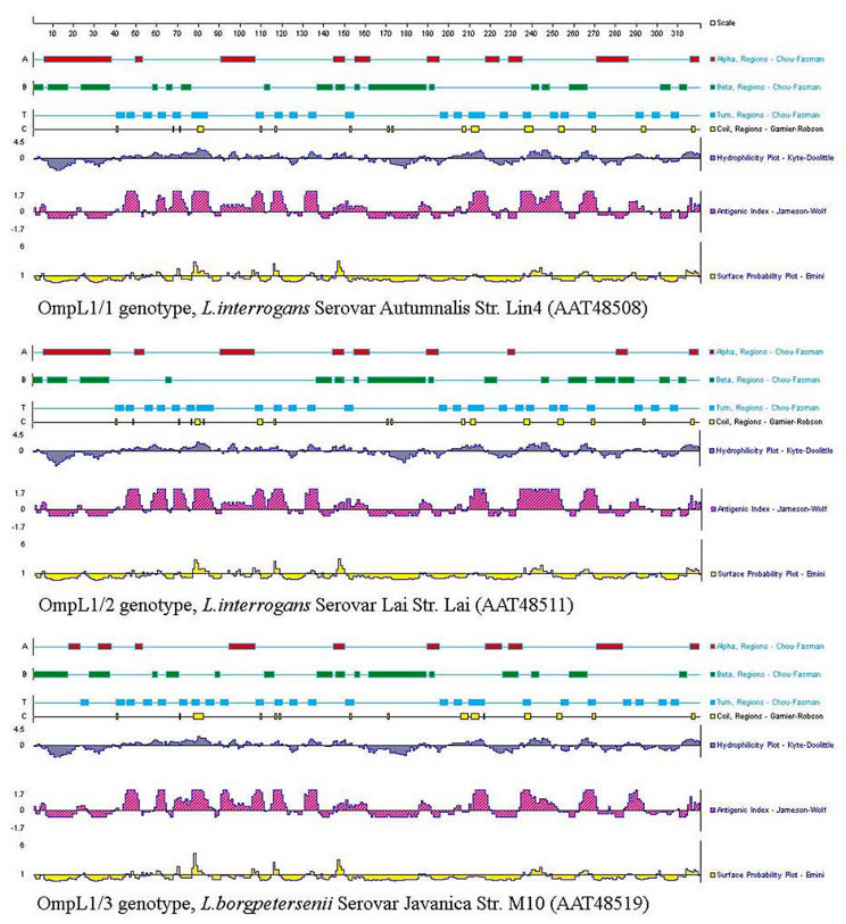

Figure 2

Comparison of the predicted secondary structures and antigenic index of OmpLI proteins. This figure shows the upper quartile, for the full image please see Additional file 2 . The related strains of the same gene type just show the same predicted structure topology. Thus, only the results from three representative strains are showed here.

Hebdomadis serovars $[3,11,25]$. Our study showed that all the 163 clinical strains of different pathogenic Leptospiral serogroup/serovars belong to either the ompL1/1 or ompL1/2 group (data not shown). Thus, we conclude that leptospires from the ompL1/1 and ompL1/2 groups are the most prevalent strains in China.

In this study, immunization with either rOmpL1/1, rOmpL1/2 or rOmpL1/3 proteins could enhance significantly survival of guinea pigs lethally challenged with pathogenic Leptospira species (Table 5). The immunoprotective rates in the groups, in which animals received a rOmpL1 for immunization and challenge with the same ompL1 gene type, appeared to be higher than those being challenged with different ompL1 gene types.

In a previous study [35], we found L. interrogans serovar Lai strain Lai could adhere to macrophages, and we here show that adherence to macrophages could be blocked with antisera against any of the rOmpL1 proteins, confirming cross-immunogenicity of OmpL1 proteins from the three different groups. All these data collectively suggest that OmpL1 is likely a genus-specific antigen. 


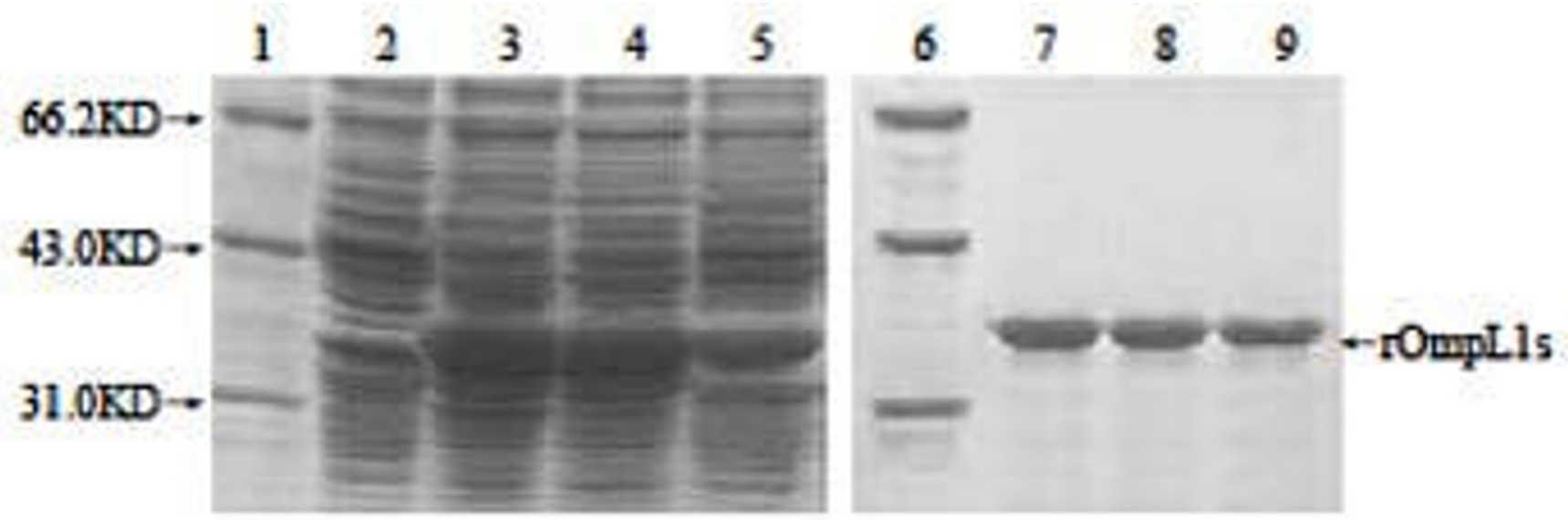

Figure 3

Expression and purification of recombinant OmpLI proteins. Lanes I and 6: protein markers (BioColor); lane 2: PET42a with no inserted ompLI genes; lanes 3 to 5: the expressed $\mathrm{rOmpLI} / \mathrm{I}, \mathrm{rOmpLI} / 2$ and $\mathrm{rOmpLI} / 3$, respectively; lanes 7 to 9: the purified $\mathrm{rOmpLI} / \mathrm{I}, \mathrm{rOmpLI} / 2$ and $\mathrm{rOmpLI} / 3$, respectively.

\section{Conclusion}

OmpL1 is a transmembrane protein extensively expressed in pathogenic leptospires. Although the ompL1 gene can belong to any of three different gene types, the OmpL1 proteins expressed by different gene types have conserved immunogenicity and the specific antibodies generally exist in sera of leptospirosis patients. OmpL1 should thus be viewed as a potential candidate of genus-specific antigen for the development of new universal vaccines and serodiagnostic methods for leptospirosis.

\section{Methods}

Leptospiral strains and serum specimens

The National Institute for the Control of Pharmaceutical and Biological Products (NICPBP) in Beijing, China, pro- vided all 15 official Chinese standard strains belonging to fifteen different pathogenic serogroups of Leptospira. In addition, 163 clinical pathogenic Leptospiral isolates and 385 serum specimens from leptospirosis patients with MAT titers of $\geq 1: 100$ were provided by the Centers of Disease Prevention and Control of Sichuan, Anhui and Zhejiang provinces in China during 2004-2007 (Table 1). All the leptospiral strains were cultured in liquid Korthof medium containing $8 \%$ rabbit serum at $28^{\circ} \mathrm{C}[2,25]$. All the patients were clinically diagnosed suffering from acute leptospirosis based on their medical history and clinical symptoms, including fevers, jaundice, hemorrhaging, myalgia and lymphadenectasis, as well as laboratory examination. Finally, 36 sera samples with negative results by MAT from healthy individuals for routine soma-

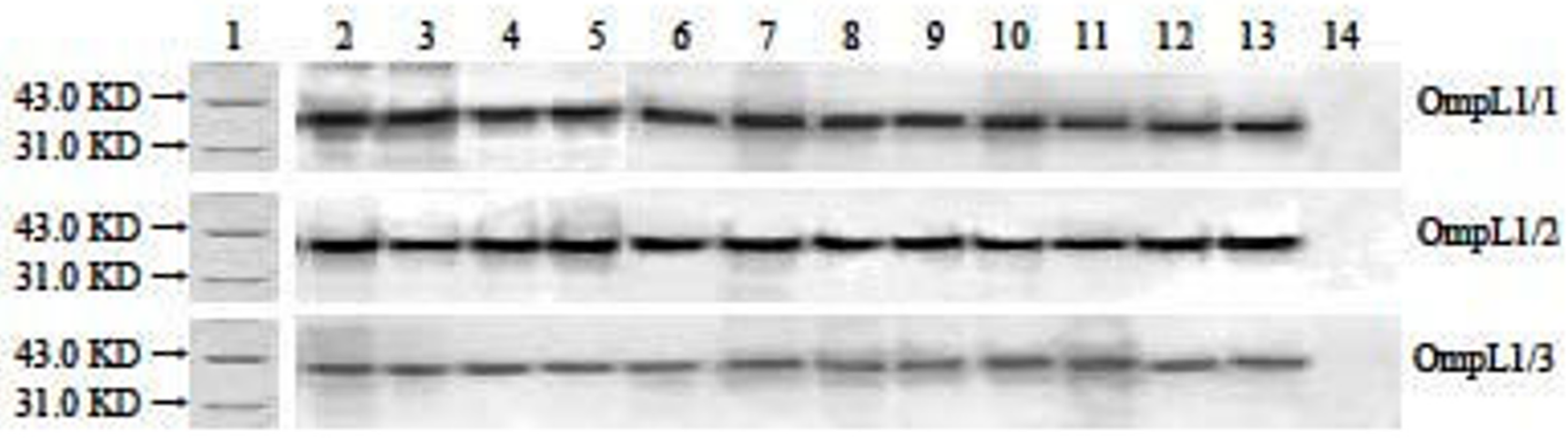

\section{Figure 4}

Recognition of purified rOmpLI proteins by sera from leptospirosis patients. Lane I: protein markers (BioColor); lanes 2-I3: the rOmpLI/I, rOmpLI/2 and rOmpLI/3 hybridizing with the antisera from leptospirosis patients; lane I3: normal human serum used as control. 

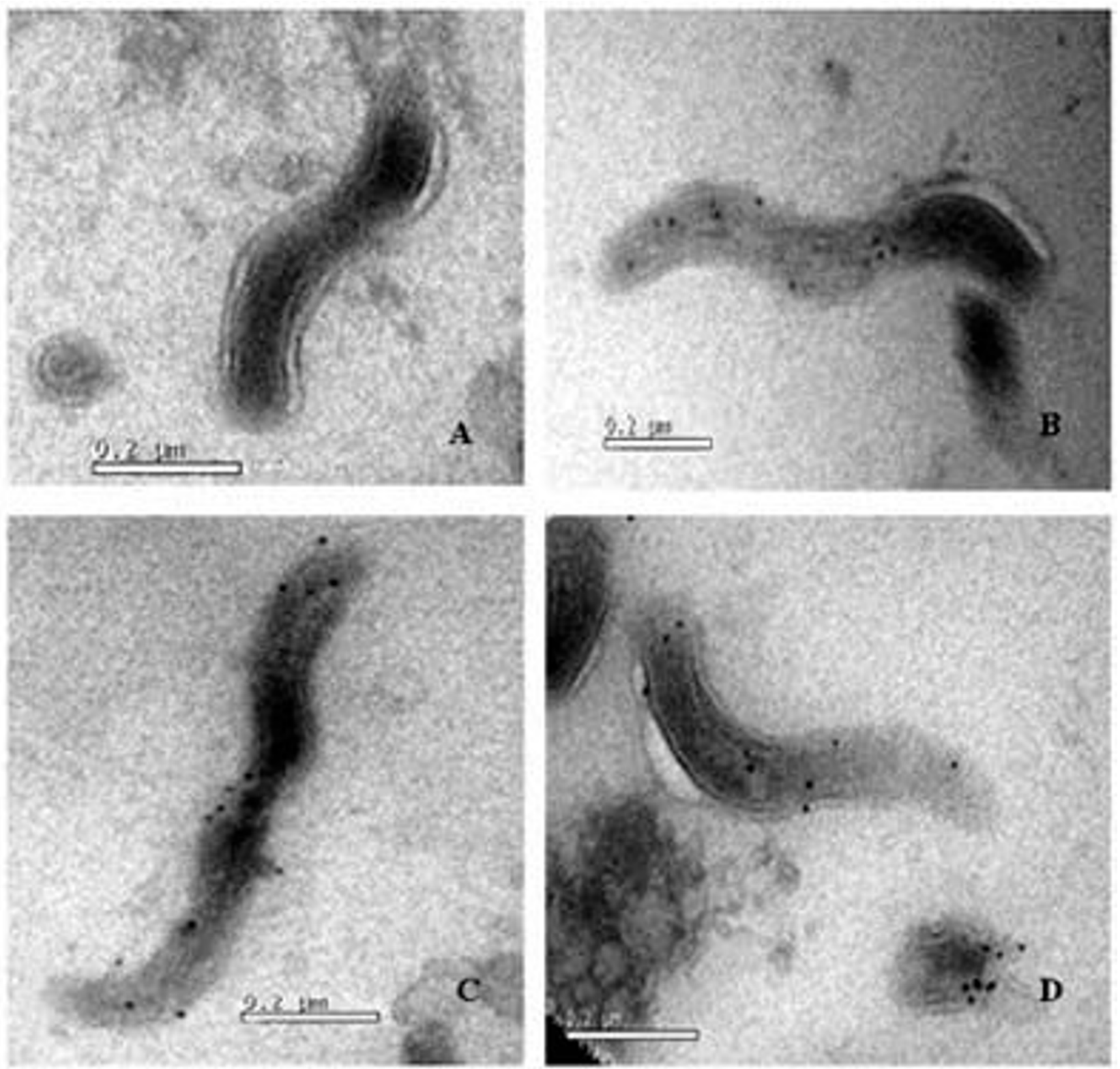

\section{Figure 5}

The localization of OmpLI on the surface of leptospires. A: negative control; B to D: the immunogold particles binding to OmpLI/I, OmpLI/2 and OmpLI/3 on the surface of $L$. interrogans serovar Autumnalis strain Lin 4, serovar Lai strain Lai, and $L$. borgpetersenii serovars Ballum strain Pishu, respectively.

toscopy were offered by the First Affiliated Hospital of Zhejiang University. Informed written consent for sample collection was obtained from all participants and individuals with ethical approval from the Ethics Committee of Zhejiang University. This research was conducted in accordance with the Declaration of Helsinki and with the Guide for Care and Use of Laboratory Animals as adopted and promulgated by the United States National Institutes of Health. All experimental protocols were approved by the Ethics Committee of Zhejiang University.

\section{Cell line and cell culture}

The murine monocyte/macrophage-like cell line, J774A.1, was provided by the Cell Bank of the Institute of Cell Biology in Shanghai, Chinese Academy of Science, and was maintained in RPMI 1640 medium (GiBco, Grand Island, 
Table 3: MAT titers among anti-rOmpLI antisera and I 78 leptospiral strains

\begin{tabular}{|c|c|c|c|c|c|}
\hline \multirow[t]{2}{*}{ Strain } & \multirow[t]{2}{*}{ Serovar } & \multirow[t]{2}{*}{ Gene type } & \multicolumn{3}{|c|}{ MAT titer (I:xxx) } \\
\hline & & & Anti-OmpLI/I & Anti-OmpLI/2 & Anti-OmpLI/3 \\
\hline \multicolumn{6}{|c|}{ Standards $(n=15)$} \\
\hline Lai & Lai & 2 & 400 & 400 & 200 \\
\hline M 10 & Javanica & 3 & 100 & 100 & 400 \\
\hline Lin & Canicola & 2 & 200 & 400 & 100 \\
\hline Pishu & Ballum & 3 & 100 & 200 & 400 \\
\hline Tian & Pyrogenes & 3 & 100 & 100 & 400 \\
\hline $\operatorname{Lin} 4$ & Autumnalis & I & 400 & 400 & 200 \\
\hline $65-9$ & Australis & 2 & 200 & 400 & 100 \\
\hline Luo & Pomona & 2 & 200 & 400 & 100 \\
\hline $\operatorname{Lin} 6$ & Grippotyphosa & 1 & 400 & 400 & 200 \\
\hline P 7 & Hebdomadis & 2 & 200 & 400 & 100 \\
\hline L 37 & Paidjan & 2 & 200 & 400 & 100 \\
\hline $55-52$ & Tarassovi & 3 & 100 & 200 & 400 \\
\hline L 105 & Manhao II & 2 & 200 & 400 & 100 \\
\hline L 183 & Wolffi & 1 & 400 & 200 & 100 \\
\hline Nan 10 & Mini & 3 & 100 & 100 & 200 \\
\hline \multicolumn{6}{|c|}{ Isolates $(n=163)$} \\
\hline 85 & Lai & & $200 \sim 400$ & $200 \sim 800$ & $100 \sim 200$ \\
\hline 5 & Canicola & & 200 & 400 & 100 \\
\hline 4 & Autumnalis & & 400 & $200 \sim 400$ & 100 \\
\hline 5 & Australis & & 200 & 400 & 100 \\
\hline 18 & Pomona & & $200 \sim 400$ & $200 \sim 800$ & $100 \sim 200$ \\
\hline 11 & Grippotyphosa & & $400 \sim 800$ & $200 \sim 400$ & $100 \sim 200$ \\
\hline 15 & Hebdomadis & & $200 \sim 400$ & $200 \sim 800$ & $100 \sim 200$ \\
\hline 20 & Medanesis & & 400 & $200 \sim 400$ & $100 \sim 200$ \\
\hline
\end{tabular}

USA) supplemented with $10 \%$ fetal bovine serum (FBS) (GiBco), and $100 \mathrm{U} / \mathrm{ml}$ penicillin and $100 \mu \mathrm{g} / \mathrm{ml}$ streptomycin. The cells were cultured in $5 \% \mathrm{CO}_{2}$ at $37^{\circ} \mathrm{C}$.

\section{Amplification and sequencing of ompLI genes}

Leptospiral DNA was extracted using Bacterial Genomic DNA Extraction Kit (BioColor BioScience \& Technology Co., Shanghai, China) and then dissolved in TE buffer. Density and purity of the extracted DNAs were detected by UV spectrophotometery. One pair of primers was applied to amplify the entire ompL1 gene. The upstream primer was 5'-CCG CATATG (Nde I) ATC CGT AAC ATA AGT AAG-3' and the downstream primer was 5'-CCG CTCGAG (Xho I) GAG TTC GTG TTT ATA ACC-3'. A High Fidelity PCR Kit (TaKaRa, Dalian, China), in which Taq-Pfu mixture is used as DNA polymerase, was used to amplify the target gene. The total volume per PCR was $50 \mu \mathrm{l}$ which included 20 pmol of each of the primers, $2.5 \mathrm{U}$ Taq-Pfu DNA polymerase, and 100 ng DNA templates. The reaction mixture was initiated by incubation at $94^{\circ} \mathrm{C}$ for 5 min, followed by 30 cycles of amplification at $94^{\circ} \mathrm{C}$ for 30 $\mathrm{s}, 55^{\circ} \mathrm{C}$ for $30 \mathrm{~s}$ and $72^{\circ} \mathrm{C}$ for $90 \mathrm{~s}$, and then incubation at $72^{\circ} \mathrm{C}$ for $10 \mathrm{~min}$. The products were detected in $1.5 \%$ ethidium bromide pre-stained agarose gel by agarose electrophoresis. The target products were predicted to be 960 base pairs (bp) in size. To obtain more accurate sequence data, the PCR products were purified using PCR Products Purification Kit (BioColor) and then ligated into plasmid pMD 18-T using T-A Cloning Kit (TaKaRa) [26]. The cloned ompL1 genes of 15 standard strains and 39 clinical strains were sequenced by Invitrogen (Shanghai, China).

\section{Phylogenetic analysis and secondary structure prediction of OmpLI protein}

The similarity and homology of sequences were first evaluated with the BLASTN program of NCBI. Alignments were carried out using ClustalX 1.83 software [27] and manually adjusted using GeneDoc 2.7 software. The amino acid sequences were deduced from their nucleotide sequences. Phylogenetic analysis was carried out with Maximum Parsimony (MP) and Maximum Likelihood (ML) optimality criteria of the PAUP* package (Version 4.0b10) [28] and MEGA 3.1 software [29]. And the probability prediction for secondary structures [30,31], including antigenic analysis [32] of OmpL1 proteins, was computed using the protean program in DNAStar ${ }^{\mathrm{TM}}$ software package.

\section{Prokaryotic expression and preparation of antisera against OmpLI proteins}

The recombinant plasmids $p M D 18$ - $T$-ompL1/1/2/3 as well as vector pET42a (Novagen, USA) were respectively 
Table 4: ELISA detection of rOmpLI-IgG/IgM in sera of leptospirosis patients

\begin{tabular}{|c|c|c|c|c|c|c|c|c|}
\hline \multirow[t]{2}{*}{ Sera } & \multirow[t]{2}{*}{ Cases (n) } & \multirow[t]{2}{*}{ Dilution (I:xxx) } & \multicolumn{3}{|c|}{ IgG-ELISA positive (n) } & \multicolumn{3}{|c|}{ IgM-ELISA positive (n) } \\
\hline & & & rOmpLI/I & $\mathrm{rOmpLI} / 2$ & rOmpLI/3 & rOMPLI/I & rOMPLI/2 & $\mathrm{rOMPLI} / 3$ \\
\hline \multicolumn{9}{|l|}{ Patients infected with: } \\
\hline \multirow[t]{3}{*}{ Icterohaemorrhagia } & 191 & 50 & I & l & I & 145 & 161 & 139 \\
\hline & & 100 & 159 & 187 & 149 & 132 & 152 & 128 \\
\hline & & 200 & 147 & 162 & 135 & 1 & 1 & l \\
\hline \multirow[t]{3}{*}{ Canicola } & 11 & 50 & I & I & I & 9 & 11 & 9 \\
\hline & & 100 & 10 & 11 & 9 & 8 & 9 & 6 \\
\hline & & 200 & 8 & 10 & 6 & l & l & l \\
\hline \multirow[t]{3}{*}{ Autumnalis } & 13 & 50 & 1 & I & I & 13 & II & 9 \\
\hline & & 100 & 13 & 12 & 10 & 10 & 8 & 7 \\
\hline & & 200 & 12 & 9 & 7 & 1 & 1 & 1 \\
\hline \multirow[t]{3}{*}{ Pomona } & 44 & 50 & 1 & l & l & 38 & 41 & 31 \\
\hline & & 100 & 38 & 43 & 33 & 31 & 35 & 26 \\
\hline & & 200 & 33 & 37 & 27 & 1 & 1 & 1 \\
\hline \multirow[t]{3}{*}{ Australis } & 13 & 50 & I & I & I & 12 & 13 & 10 \\
\hline & & 100 & 12 & 13 & 10 & 10 & 11 & 7 \\
\hline & & 200 & 10 & 11 & 8 & 1 & I & 1 \\
\hline \multirow[t]{3}{*}{ Grippotyphosa } & 31 & 50 & 1 & 1 & l & 29 & 26 & 22 \\
\hline & & 100 & 30 & 26 & 23 & 23 & 21 & 16 \\
\hline & & 200 & 26 & 23 & 16 & l & I & 1 \\
\hline \multirow[t]{3}{*}{ Hebdomadis } & 37 & 50 & 1 & 1 & 1 & 34 & 35 & 30 \\
\hline & & 100 & 33 & 36 & 30 & 29 & 30 & 25 \\
\hline & & 200 & 28 & 31 & 24 & l & I & l \\
\hline \multirow[t]{3}{*}{ Sejroe } & 45 & 50 & 1 & 1 & 1 & 41 & 37 & 36 \\
\hline & & 100 & 43 & 38 & 35 & 37 & 32 & 28 \\
\hline & & 200 & 37 & 33 & 29 & I & I & l \\
\hline \multirow[t]{3}{*}{ Total } & 385 & 50 & 1 & 1 & 1 & 321 & 335 & 286 \\
\hline & & 100 & 338 & 366 & 299 & 280 & 298 & 243 \\
\hline & & 200 & 301 & 316 & 252 & I & I & I \\
\hline \multirow[t]{6}{*}{ Healthy individuals: } & 36 & 50 & 1 & 1 & 1 & $0.20 \pm 0.06$ & $0.20 \pm 0.07$ & $0.19 \pm 0.07$ \\
\hline & & Cut-off & 1 & I & l & 0.38 & 0.41 & 0.40 \\
\hline & & 100 & $0.17 \pm 0.05$ & $0.18 \pm 0.05$ & $0.17 \pm 0.06$ & $0.18 \pm 0.05$ & $0.17 \pm 0.06$ & $0.17 \pm 0.05$ \\
\hline & & Cut-off & 0.32 & 0.33 & 0.35 & 0.33 & 0.35 & 0.32 \\
\hline & & 200 & $0.14 \pm 0.04$ & $0.13 \pm 0.05$ & $0.15 \pm 0.04$ & l & I & 1 \\
\hline & & Cut-off & 0.26 & 0.28 & 0.27 & I & l & I \\
\hline
\end{tabular}

Note: the mean at $\mathrm{OD}_{490}+3 \mathrm{SD}=$ cut-off value

digested with Nde I and Xho I (TaKaRa). The recovered ompL1 segments were respectively linked with the linearized pET42a by T4 DNA ligase (TaKaRa) and then transformed into E. coli BL21DE3 (Novagen). The three constructed prokaryotic expression systems were induced with $0.5 \mathrm{mM}$ IPTG in LB medium to express recombinant OmpL1 (rOmpL1). Expression of rOmpL1 was examined by SDS-PAGE plus Gel Image Analyzor (BioRad, USA). The expressed rOmpL1 proteins were extracted and purified by Ni-NTA affinity chromatography. New Zealand white Rabbits provided by the Laboratory Animal Center, Zhejiang University, were immunized intradermally with each of the purified rOmpL1 proteins pre-mixed with Freund's adjuvant for four times at an interval of once a week. On the 15th day after the last immunization, the rabbit sera were collected and the Immunodiffusion test was used to examine the titers of antisera [24].

\section{Western blot assay}

Western blot analysis was used to identify the immunoreactivity of rOmpL1 proteins using 12 serum samples from the patients diluted at 1:1000 (the same dilution of normal human sera was used as control) as the primary antibodies, and 1:3000 diluted HRP-labeled goat anti-human IgG (Jackson ImmunoResearch Laboratories Inc., USA) as the secondary antibody.

\section{Immuno-electron microscopy}

Freshly-cultured $L$. interrogans serovar Autumnalis strain Lin 4 (ompL1/1 gene type), serovar Lai strain Lai (ompL1/2 gene type), and $L$. borgpetersenii serovar Ballum strain Pishu (ompL1/3 gene type) were centrifuged at 12, 000 $\mathrm{rpm}$ for $15 \mathrm{~min}$ at $15^{\circ} \mathrm{C}$. The precipitates were fixed with fresh $2 \%$ paraformaldehyde at $4{ }^{\circ} \mathrm{C}$ for $24 \mathrm{~h}$. Prepared sections were exposed to $5 \% \mathrm{FBS}$ at room temperature for 30 

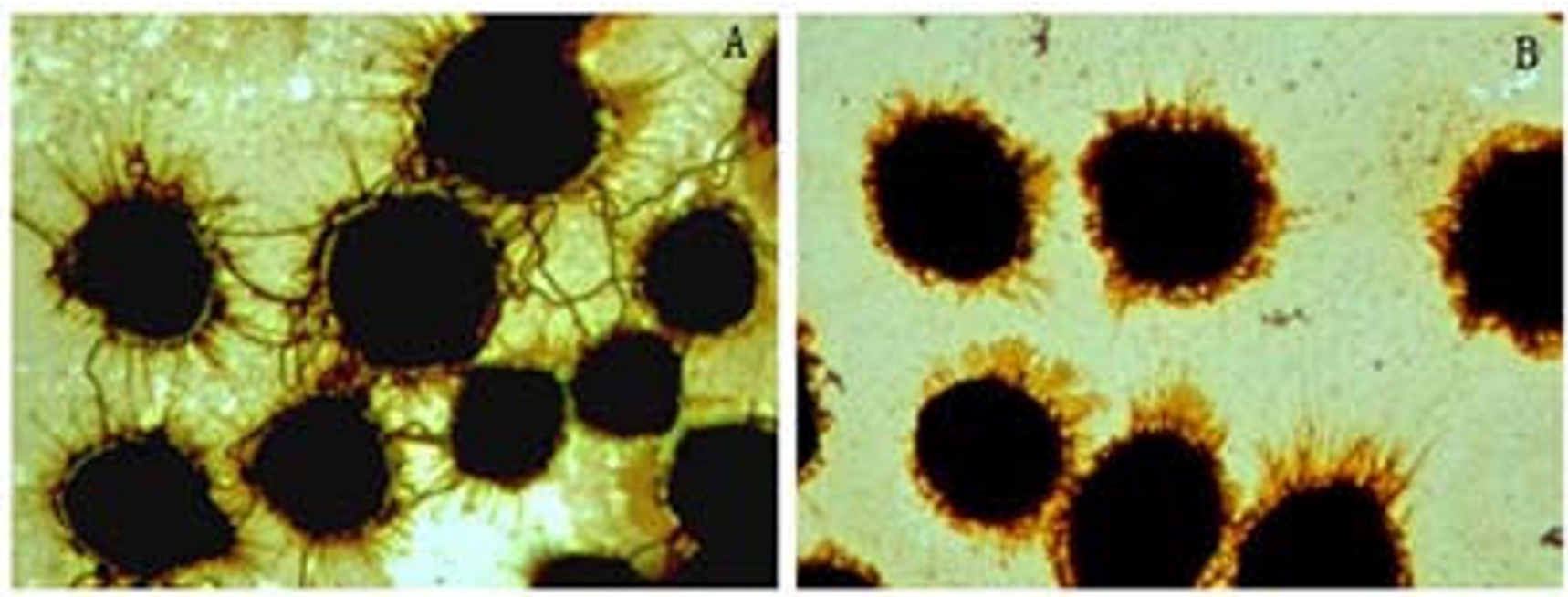

\section{Figure 6}

Inhibition of leptospiral adherence to J744A.I macrophages in the presence anti-rOmpLI antiserum. A: Leptospires binding to macrophages in the presence of irrelevant antisera. B: inhibition of leptospiral binding to macrophages in the presence of antiserum against recombinant $\mathrm{OmpLI}$ protein (amplification $\times 1000$ ).

min to block unspecific antigens, and then incubated with each 1:1000 diluted rOmpL1s rabbit antisera or preimmune normal rabbit sera (negative control) as the first antibody and 1:2000 diluted colloidal gold (12 nm)labeled goat anti-rabbit IgG (Jackson ImmunoResearch Laboratories) as the second antibody. The locations of OmpL1s were determined under transmission electron microscope (Philips TECNAL-10, Eindhoven, Holland)[16].

\section{Microscopic agglutination test}

The microscopic agglutination test (MAT) was used to determine cross-immunoagglutination under dark-field microscopy using rabbit antisera against the rOmpL1 proteins reacting with the 15 freshly-cultured standard strains

Table 5: Immunoprotective effects of rOmpLI proteins in guinea pigs

\begin{tabular}{|c|c|c|c|c|c|c|c|}
\hline \multirow[t]{2}{*}{ Group } & \multirow[t]{2}{*}{ Animals (n) } & \multicolumn{3}{|c|}{ Immunizing dosage $(\mathrm{mg} / \mathrm{kg})$} & \multirow{2}{*}{$\begin{array}{c}\text { Infecting Leptospiral } \\
\text { strain }\end{array}$} & \multirow{2}{*}{$\begin{array}{l}\text { Survival/Death } \\
(\mathrm{n} / \mathrm{n})\end{array}$} & \multirow{2}{*}{$\begin{array}{c}\text { Protective rate } \\
\text { (\%) }\end{array}$} \\
\hline & & rOmpLI/I & rOmpLI/2 & $\mathrm{rOmpL} / 3$ & & & \\
\hline $\mathrm{Al}$ & 8 & 1.0 & l & l & Lai & $3 / 5$ & 37.5 \\
\hline $\mathrm{A} 2$ & 8 & 2.0 & 1 & 1 & Lai & $5 / 3$ & 62.5 \\
\hline $\mathrm{A} 3$ & 8 & 1.0 & I & l & Lin 4 & $5 / 3$ & 62.5 \\
\hline A4 & 8 & 2.0 & I & I & Lin 4 & $7 / 1$ & 87.5 \\
\hline A5 & 8 & 1.0 & I & I & Pishu & $2 / 6$ & 25.0 \\
\hline A6 & 8 & 2.0 & l & l & Pishu & $3 / 5$ & 37.5 \\
\hline $\mathrm{BI}$ & 8 & l & 1.0 & l & Lai & $5 / 3$ & 62.5 \\
\hline B2 & 8 & I & 2.0 & I & Lai & $6 / 2$ & 75.0 \\
\hline B3 & 8 & l & 1.0 & l & $\operatorname{Lin} 4$ & $4 / 4$ & 50.0 \\
\hline B4 & 8 & 1 & 2.0 & I & Lin 4 & $5 / 3$ & 62.5 \\
\hline B5 & 8 & I & 1.0 & 1 & Pishu & $2 / 6$ & 25.0 \\
\hline B6 & 8 & I & 2.0 & I & Pishu & $3 / 5$ & 37.5 \\
\hline $\mathrm{Cl}$ & 8 & I & 1 & 1.0 & Lai & $2 / 6$ & 25.0 \\
\hline $\mathrm{C} 2$ & 8 & 1 & I & 2.0 & Lai & $3 / 5$ & 37.5 \\
\hline $\mathrm{C} 3$ & 8 & 1 & I & 1.0 & Lin 4 & $3 / 5$ & 37.5 \\
\hline C4 & 8 & 1 & 1 & 2.0 & Lin 4 & $4 / 4$ & 50.0 \\
\hline $\mathrm{C} 5$ & 8 & I & I & 1.0 & Pishu & $5 / 3$ & 62.5 \\
\hline C6 & 8 & I & 1 & 2.0 & Pishu & $6 / 2$ & 75.0 \\
\hline DI & 8 & 1 & 1 & 1 & Lai & $0 / 8$ & 1 \\
\hline D2 & 8 & 1 & 1 & I & Lin 4 & $0 / 8$ & I \\
\hline D3 & 8 & 1 & 1 & I & Pishu & $0 / 8$ & I \\
\hline
\end{tabular}


and 163 clinical isolates of leptospires, in which normal saline was used as negative control $[2,33]$.

\section{ELISA assay with rOmpLI proteins}

Enzyme-linked immunosorbent assays (ELISAs) were used to detect rOmpL1/1 or rOmpL1/2-specific IgM or IgG. Briefly, 96-well plates were coated with $50 \mu \mathrm{g} / \mathrm{ml}$ rOmpL1/1 or rOmpL1/2 (100 $\mu$ l per well $)$ at $4{ }^{\circ} \mathrm{C}$ overnight, and then incubated with 5\% FBS for $30 \mathrm{~min}$ to block unspecific binding. Using the diluted serum specimens from patients or normal individuals (1:50 or 1:100 dilution for IgM detection, and 1:100 or 1:200 dilution for IgG detection) as the primary antibody, HRP-labeling goat anti-human IgM (1:3000 dilution) or IgG (1:4000 dilution) (Jackson ImmunoResearch Laboratories) as the secondary antibody, and o-phenvlenediamine (OPD) as the substrate, the rOmpL1 proteins-specific IgM or IgG were examined under a Microplate Reader (Model 550, BioRad). $\mathrm{OD}_{490}$ values over the mean plus $3 \mathrm{SD}$ of the 36 normal serum specimens were defined as positive [34].

\section{Adherence inhibition test}

J774A. 1 cells $\left(1 \times 10^{5}\right.$ cells in $1 \mathrm{ml}$ medium per well $)$ were inoculated in 12-well plates (Corning, USA) containing glass cover slips, incubated at $37^{\circ} \mathrm{C}$ for $24 \mathrm{~h}$. Freshlygrown cultures of $L$. interrogans serovar Lai strain Lai were centrifuged at $10,000 \mathrm{rpm}$ for $15 \mathrm{~min}$ at $15^{\circ} \mathrm{C}$, and the precipitates were then suspended in antibiotics-free RPMI 1640 medium (GiBco) to a final concentration of $10^{8} / \mathrm{ml}$. The antisera against rOmpL1 proteins were serially double-diluted with antibiotics-free RPMI 1640 medium (1:2 to $1: 32$ ), then mixed with the same volumes of each leptospiral suspension. The mixtures were incubated at $37^{\circ} \mathrm{C}$ for $1 \mathrm{~h}$. The medium in the 12-well plates was removed, and then the plates were repeatedly washed with antibiotic-free RPMI1640 medium. The mixtures were added into the plates to incubate at $37^{\circ} \mathrm{C}$ for $1 \mathrm{~h}$. After the incubation, the plates were repeatedly washed with PBS to remove non-adhered leptospires, and the Fontana silverstained leptospires adhering J774A.1 cells were observed under light microscope [35]. In this test, preimmune rabbit serum instead of the antisera was used as control.

\section{Immunoprotective test in guinea pigs}

Dunkin-Hartley guinea pigs ( $150 \pm 5 \mathrm{~g}, 3$ weeks old) used in this study were provided by Laboratory Animal Center of Zhejiang University (certificate no. SCXK [zhe]20070030). L. interrogans serovar Lai strain Lai, serovar Autumnalis strain Lin 4, and L. borgpetersenii serovar Bullum stain Pishu were maintained by serial passage in guinea pigs for preservation of virulence before use for challenge. Eighteen groups of guinea pigs (A1-6, B1-6, and C1-C6) were subcutaneously immunized twice at an interval of once a week with different dosages of rOmpL1/1, rOmpL1/2 and rOmpL1/3, respectively. In addition, another three groups of guinea pigs (D1-3) were immunized with bovine serum albumin (BSA) (Sigma, USA) as control. Each protein antigen was pre-mixed with $0.7 \mathrm{mg}$ aluminum hydroxide (Sigma) [36]. On the 15th day after the last immunization, the animals were challenged intraperitoneally with lethal doses of strain Lai, strain Lin 4 or strain Pishu and then observed for another 7 days.

\section{Authors' contributions}

HD carried out the molecular genetic studies, immunoassays, drafted the manuscript. YH: carried out the immunoelectron microscope assay. FX carried out the bioinformatics analysis and immunoprotective test. JM carried out the immunoassays, cultured the leptospires. DS participated in the design of the study, analysis and interpretation of data. DO participated in study design and coordination, revised the manuscript. JY conceived of the study, and participated in its design and coordination. All authors read and approved the final manuscript, agreed to be published.

\section{Additional material}

\section{Additional file 1}

Full image of maximum parsimony trees for ompL1 nucleotide sequences (A) and its amino acid sequences (B) of 15 standard strains. This figure showed the phylogenetic relationship of nucleotide sequence and amino acid sequences of Chinese 15 standard strains of pathogenic leptospires.

Click here for file

[http://www.biomedcentral.com/content/supplementary/14712180-8-223-S1.tiff]

\section{Additional file 2}

Full image of comparison of the predicted secondary structures and antigenic index of OmpL1 proteins. This figure showed the predicted secondary structures and antigenic index of OmpL1 proteins belongs to three gene types (ompL1/1, ompL1/2, and ompL1/3).

Click here for file

[http://www.biomedcentral.com/content/supplementary/14712180-8-223-S2.tiff]

\section{Acknowledgements}

This work was supported by Key Science and Technique Plan project of Zhejiang Province, China (Grant No. 2006C24003) and National science and technology Key program of China (Grant No. 2008ZX 10404). We thank the CDCs of China for providing the clinical strains of pathogenic leptospires and serum specimens from leptospirosis patients.

\section{References}

I. Levett PN: Leptospirosis. Clin Microbiol Rev 200I, I 4:296-326.

2. Faine S, Adher B, Bloin C, Perolat P: Leptospira and leptospirosis. 2nd edition. Melbourne, Australia: MedSci; 1999.

3. McBride AJ, Athanazio DA, Reis MG, Ko Al: Leptospirosis. Curr Opin Infect Dis 2005, I 8:376-386.

4. Bharti AR, Nally JE, Ricaldi JN, Matthias MA, Diaz MM, Lovett MA, Levett PN, Gilman RH, Willig MR, Gotuzzo E, Vinetz JM, Peru-United 
States Leptospirosis Consortium: Leptospirosis: a zoonotic disease of global importance. Lancet Infect Dis 2003, 3:757-77I.

5. Pappas G, Papadimitriou P, Siozopoulou V, Christou L, Akritidis N: The globalization of leptospirosis: worldwide incidence trends. Int J Infect Dis 2008, I 2:35 I-357.

6. Sejvar J, Bancroft E, Winthrop K, Bettinger J, Bajani M, Bragg S, Shutt K, Kaiser R, Marano N, Popovic T, Tappero J, Ashford D, Mascola L, Vugia D, Perkins B, Rosenstein N, Eco-Challenge Investigation Team: Leptospirosis in "Eco-Challenge" athletes, Malaysian Borneo, 2000. Emerg Infect Dis 2003, 9:702-707.

7. Sonrier C, Branger C, Michel V, Ruvoën-Clouet N, Ganière JP, AndréFontaine G: Evidence of cross-protection within Leptospira interrogans in an experimental model. Vaccine 2000, 19:86-94.

8. Koizumi N, Watanabe $\mathrm{H}$ : Leptospirosis vaccines: past, present, and future. J Postgrad Med 2005, 5 I:2 I 0-2 I 4.

9. Campagnolo ER, Warwick MC, Marx HL Jr, Cowart RP, Donnell HD Jr, Bajani MD, Bragg SL, Esteban JE, Alt DP, Tappero JW, Bolin CA Ashford DA: Analysis of the 1998 outbreak of leptospirosis in Missouri in humans exposed to infected swine. J Am Vet Med Assoc 2000, 216:676-682.

10. Venkataraman KS, Nedunchelliyan S: Epidemiology of an outbreak of leptospirosis in man and dog. Comp Immunol Microbiol Infect Dis 1992, 15:243-247.

II. Gong ZY, Jiang LP, Chen EF, Wang Z, Li JF, Fu GM, Cai CL, Xu FH: Epidemiological surveillance of leptospirosis in 1997-2002 in Zhejiang Province. Zhonghua Liu Xing Bing Xue Za Zhi 2004, 25:1091.

12. Shi MH, Tu YR, Li QJ: Study on geographical distribution of leptospirosis in China. Zhonghua Liu Xing Bing Xue Za Zhi 1995 16:259-62.

13. Martinez R, Perez A, Quinones Mdel C, Cruz R, Alvarez A, Armesto M, Fernández C, Menéndez J, Rodríguez I, Baró M, Díaz M, Rodríguez J, Sierra G, Obregón AM, Toledo ME, Fernández N: Efficacy and safety of a vaccine against human leptospirosis in Cuba. Rev Panam Salud Publica 2004, I 5:249-255.

14. Yan Y, Chen Y, Liou W, Ding J, Chen J, Zhang J, Zhang A, Zhou W, Gao Z, Ye X, Xiao Y: An evaluation of the serological and epidemiological effects of the outer envelope vaccine to Leptospira . J Chin Med Assoc 2003, 66:224-230.

15. Rathinam SR: Ocular leptospirosis. Curr Opin Ophthalmol 2002, 13:381-386.

16. Haake DA, Champion Cl, Marfinich C, Shang ES, Blanco DR, Miller JN, Lovett MA: Molecular cloning and sequence analysis of the gene encoding OmpLI, a transmembrane outer membrane protein of pathogenic Leptospira spp. J Bacteriol 1993, 175(13):4225-4234

17. Shang ES, Exner MM, Summers TA, Martinich C, Champion Cl, Hancock RE, Haake DA: The rare outer membrane protein, OmpLI, of pathogenic Leptospira species is a heat-modifiable porin. Infect Immun 1995, 63:3174-3181.

18. Haake DA, Mazel MK, McCoy AM, Milward F, Chao G, Matsunaga J, Wagar EA: Leptospiral outer membrane proteins OmpLI and LipL4I exhibit synergistic immunoprotection. Infect Immun 1999, 67:6572-6582

19. Haake DA, Suchard MA, Kelley MM, Dundoo M, Alt DP, Zuerner RL: Molecular evolution and mosicism of leptospiral outer membrane proteins involves horizontal DNA transfer. J Bateriol 2004, I 86:2818-2/28.

20. Sonrier C, Branger C, Michel V, Ruvoën-Clouet N, Ganière JP, AndréFontaine G: Evidence of cross-protection within Leptospira interrogans in an experimental model. Vaccine 2000, 19:86-94

21. Cullen PA, Cordwell SJ, Bulach DM, Haake DA, Adler B: Global analysis of outer membraneproteins from Leptospira interrogans serovar Lai. Infect Immun 2002, 70:23II -23I8.

22. Cullen PA, Hake DA, Adler B: Outer membrane proteins of pathogenic spirochetes. FEMS Microbiol Rev 2004, 28:29I-318.

23. Palaniappan RU, Ramanujam S, Chang YF: Leptospirosis: pathogenesis, immunity, and diagnosis. Curr Opin Infect Dis 2007, 20:284-292.

24. Zhang $X Y, Y u, Y, H e P$, Zhang $Y X$, Hu BY, Yang $Y$, Nie $Y X$, jiang $X G$, Zhao GP, Guo XK: Expression and comparative analysis of genes encoding outer membrane proteins LipL2I, LipL32 and OmpLI in epidemic leptospires. Acta Biochim Biophys Sin 2005, 37:649-656.

25. Dai B: Advances in research on leptospira and human leptospirosis in China. Chin Med SciJ 1992, 7:239-43.
26. Kobayashi Y: Clinical observation and treatment of leptospirosis. J Infect Chemother 200I, 7:59-68.

27. Thompson JD, Gibson TJ, Plewniak F, Jeanmougin F, Higgins DG: The Clustsal $\mathbf{X}$ windows interface: flexible strategies for multiple sequence alignment aided by quality analysis tools. Nucleic Acids Res 1997, 24:4876-4882.

28. Swofford DL: PAUP *: Phylogenetic analysis using parsimony (*and other methods). Sunderland, Massachusetts, USA: Sinauer Associates; 2002

29. Kumar S, Tamura K, Nei M: MEGA3: Integrated software for Molecular Evolutionary Genetics Analysis and sequence alignment. Brief Bioinform 2004, 5: 150-163.

30. Chou PY, Fasman GD: Prediction of secondary structure of proteins from their amino acid sequence. Adv Enzymol Relat Areas Mol Biol 1978, 47: |45- I48.

31. Kyte J, Doolittle RF: A simple method for displaying the hydropathic character of a protein. J Mol Biol 1982, I57:105-132

32. Jameson $\mathrm{BA}$, Wolf $\mathrm{H}$ : The antigenic index: a novel algorithm for predicting antigenic determinants. Comput Appl Biosci 1988, 4: $18|-| 86$.

33. Sambrook J, Fritsch EF, Maniatis T: Molecular cloning, a laboratory manual. New York, USA: Cold Spring Harbor Laboratory Press; 1989.

34. Lewis SM, Osei-Bimpong A: Haemoglobinometry in general practice. Clin Lab Haematol 2003, 25:343-346.

35. Li L, Ojcius DM, Yan J: Comparison of invasion of fibroblasts and macrophages by high- and low-virulence Leptospira strains: colonization of the host-cell nucleus and induction of necrosis by the virulent strain. Arch Microbiol 2007, 188:59।-598.

36. Levesque PM, Foster K, de Alwis U: Association between immunogenicity and adsorption of a recombinant Streptococcus pneumomiae vaccine antigen by aluminum adjuvant. Hum Vaccin 2006, 2(2):74-77.
Publish with BioMed Central and every scientist can read your work free of charge

"BioMed Central will be the most significant development for disseminating the results of biomedical research in our lifetime. "

Sir Paul Nurse, Cancer Research UK

Your research papers will be:

- available free of charge to the entire biomedical community

- peer reviewed and published immediately upon acceptance

- cited in PubMed and archived on PubMed Central

- yours - you keep the copyright
BioMedcentral 